\title{
Impacts of China's bioethanol policy on the global maize market: a partial equilibrium analysis to 2030
}

\author{
Xinru Han ${ }^{1}$ (D) $\cdot$ Yongfu Chen ${ }^{2} \cdot$ Xiudong Wang $^{1}$ \\ Received: 18 December 2020 / Accepted: 18 August 2021 / Published online: 17 September 2021 \\ (c) International Society for Plant Pathology and Springer Nature B.V. 2021
}

\begin{abstract}
Maize is a major component of China's cereal production. It is also one of the main feedstocks for China's bioethanol production. To ensure food security, there is flexibility in China's ethanol policy. In this paper, we build a multicountry and multisector partial equilibrium model to simulate the possible impacts of biofuel policy on maize markets and food security. Considering normal macroeconomic conditions, China's bioethanol promotion policy would result in a net increase in maize imports to $26 \mathrm{mmt}$ in 2030. Meanwhile, China's maize self-sufficiency ratio would decrease to $92 \%$ in 2030 as a result of the country's bioethanol promotion policy. In addition, simulation results indicate that China's bioethanol promotion policy could increase the world maize price index by $5 \%$ and the world bioethanol price index by $4 \%$ in 2030. Based on this modeling study, the Chinese government may take measures in advance to prepare for large-scale maize imports, adjust its strategy in order to make better use of the international market, and strengthen international trade and stock cooperation with maize import regions and countries.
\end{abstract}

Keywords Bioethanol policy · Global maize market · Partial equilibrium analysis · China

\section{Introduction}

Having experienced an economic boom over the past decade, China has emerged as the second largest gasoline consumer in the world, after the United States. Gasoline consumption in China in 2017 was 124 million metric tons (mmt), equal to 3.5 times its consumption in 2000 (National Bureau of Statistics of China (NBSC), 2019). A large increase in gasoline consumption results in weakened energy security, as China's crude oil self-sufficiency dropped from $68.3 \%$ in 2000 to $31.3 \%$ in 2017 (NBSC, 2019). Furthermore, increased gasoline consumption contributes to greenhouse gas (GHG) emissions and air pollution, as China's transport sector contributed $14 \%$ of the country's total carbon emissions in 2014 (Li \& Yu, 2019).

Yongfu Chen

chenyf@cau.edu.cn

1 Institute of Agricultural Economics and Development, Chinese Academy of Agricultural Sciences, Beijing 100081, China

2 College of Economics and Management, China Agricultural University, Beijing 100083, China
Renewable energy, such as bioethanol, is an important option for enhancing energy security and environmental sustainability (Koizumi, 2015; Qiu et al., 2012). The bioethanol industry may help to reduce poverty (Huang et al., 2012a, $2012 b$ ) and alleviate food insecurity by providing work opportunities (Thornhill et al., 2016). However, by changing land use and increasing food prices, biofuel also contributes to food insecurity (Grote, 2014; Popp et al., 2014; Thornhill et al., 2016). Since 2001, China has been the third largest bioethanol producer in the world, after the United States and Brazil (OECD/FAO, 2021). The production of bioethanol in China has increased from 3137 million liters in 2001 to 5000 million liters in 2005 and 10,000 million liters in 2018, with an annual growth rate of $7.1 \%$ (OECD/FAO, 2021). The rapid growth in the production of bioethanol in China is driven by policies to reduce stale maize/wheat stocks (Qiu et al., 2012; Zhang, 2015), as well as the prices of crude oil, maize, and bioethanol (Birur et al., 2008; To \& Grafton, 2015; Xu et al., 2018). 
In China, maize ${ }^{1}$ is one of the most important crops and the main material for bioethanol production, accounting for $39.1 \%$ of grain $^{2}$ production, $42.2 \%$ of cereal production, and $71.7 \%$ of bioethanol production in 2018 (NBSC, 2019; OECD/FAO, 2021). The maize used to produce bioethanol is domestic. ${ }^{3}$ However, maize is also an important feed source in China and rapid economic growth has led to an increase in meat and feed consumption. In 2019, the domestic production of maize in China was $260.8 \mathrm{mmt}$ and net imports were $4.8 \mathrm{mmt}$, thus the self-sufficiency rate was $98.2 \%$ (Chinese Academy of Agricultural Sciences, 2021). Meanwhile, the shares of feed, processing, food, and other demands were $56.4 \%, 32.1 \%, 7.0 \%$, and $4.4 \%$, respectively (Chinese Academy of Agricultural Sciences, 2021).

To feed 1.4 billion people, food security is a priority goal of the Chinese government. The core of China's food security strategy is to ensure basic self-sufficiency of cereals and absolute security of food grains (Han, 2020). While the government did not provide a specific number, $90 \%$ self-sufficiency for cereals and $95 \%$ for food grains can be considered the minimum self-sufficiency levels (Yan et al., 2019). Biofuel from maize could lead to shortages of feed, growth in imports, and price increases. In addition, the price effects on maize will also be reflected in food grain prices through substitution effects and in livestock prices. Therefore, it is important to empirically identify the impacts of bioethanol production on food security (Araujo Enciso et al., 2016; Bosch \& Zeller, 2019; Grote, 2014; Koizumi, 2015; To \& Grafton, 2015; Tomei \& Helliwell, 2016; Zilberman et al., 2013).

Cereal-to-ethanol programs and policies in China are closely monitored due to concerns from the government agency on food security and maintain flexibility. Since 2004, China has been developing maize-to-ethanol pilot programs. To further encourage the development of liquid biofuels, the Renewable Energy Law was adopted in 2015. However, with concerns for food security, the National Development and Reform Commission (NDRC) issued a policy to control the development of cereal-based bioethanol production in

\footnotetext{
${ }^{1}$ In this paper, "maize" refers to both yellow and white maize. The majority of maize in China is yellow maize, but the share of each type of maize, however, is not officially known.

2 As defined by the NBSC, "grain covers cereals, tubers and beans by type of crops" (NBSC, 2019). Cereals, beans, and potatoes accounted for $92.7 \%, 2.9 \%$, and $4.4 \%$ of China's grain production in 2018, respectively (NBSC, 2019). China used cereal and food grain (rice and wheat) rather than grain in general for the first time in 2014. For consistency with official files and previous studies, we use grain, cereal, and food grain in this study.

3 According to the General Administration of Customs of the People's Republic of China, the share of imported maize consumed in the maize-based bioethanol production provinces (Heilongjiang, Jilin, Liaoning, and Henan) was $4.19 \%$ in 2019.
}

2007. To reduce the amount of stored maize resulting from the temporary storage program (TSP) implemented in 2008 (Huang et al., 2017), the Chinese government has gradually increased its support for maize-to-ethanol programs since 2016. Recently, the Chinese government strictly limited the development of cereal-based bioethanol production again in 2020 under the background of increases in food prices relative to the COVID-19 pandemic (Devereux et al., 2020; Zimmerer \& de Haan, 2020).

The methods commonly used for policy evaluation at the micro level include propensity score matching (Han et al., 2019; Paudel et al., 2020), difference-in-difference (Chen et al., 2020; Petrick \& Zier, 2011), and regression discontinuity (Bhalla et al., 2018; Bosch \& Schady, 2019). However, from a macro perspective, previous studies have assessed the impacts of agricultural policy on cereal markets using computable general equilibrium (CGE) and partial equilibrium (PE) models (Francois \& Reinert, 1998; Karp \& Perloff, 2002; Kozicka et al., 2017; Sheng \& Song, 2019; Valin et al., 2014; Von Lampe et al., 2014). Compared with CGE models, PE models do not consider spillover effects on nonagricultural markets but can represent different agricultural policies at a deeper level (Hoang \& Meyers, 2015). Therefore, many international organizations have built multiregion and multisector PE models, i.e., the AGLINK-COSIMO model of the Organization for Economic Cooperation and Development (OECD) and the Food and Agriculture Organization (FAO) (OECD, 2007); the long-term projection model of the U.S. Department of Agriculture (USDA); the IMPACT model of the International Food Policy Research Institute (IFPRI) (Robinson et al., 2015); and the WFSD model of the Policy Research Institute, Ministry of Agriculture, Forestry, and Fisheries (PRIMAFF), Japan (Furuhashi, 2015).

Maize projections in China have also been widely simulated. Most results show that China will remain a net importer of maize in the coming decades, but the range of projections is wide. China's net import of maize in 2020-as simulated by Xu et al. (2015) is $3 \mathrm{mmt}$, while Lu et al. (2017) projected that the volume would be $11.5 \mathrm{mmt}$ in 2025 . The results of the WFSD model indicate that China's import of maize is expected to reach $9.8 \mathrm{mmt}$ by 2030 (PRIMAFF, 2021), while OECD/FAO (2021) projected that China will import $7.2 \mathrm{mmt}$ of maize by 2030 . The USDA (2021a) projects that China is expected to continue to import $7.2 \mathrm{mmt}$ of maize per year from 2021 to 2030. In a long-term projection, Sheng and Song (2019) indicate that China's maize imports are projected to increase to $57 \mathrm{mmt}$ by 2050 . Additionally, various Chinese studies have made maize projections, which can be found in the review by (Lv, 2013). However, these projections cannot be compared directly due to their different assumptions, parameters, and model structures (Fan \& 
Agcaoili-Sombilla, 1997), nor do they simulate the impacts of the recent bioethanol promotion policy on the maize supply and demand of China.

This paper aims to evaluate the impacts of China's bioethanol policy on maize markets and China's food security strategy (basic self-sufficiency of cereals) to 2030 by addressing the following questions. How will the international maize market respond under different options for China's bioethanol policies? Will China import more maize and fail to achieve the goal of basic self-sufficiency of cereals due to the acceleration of bioethanol production? Where might increased maize imports originate? We make two main contributions. First, we build a multicountry and multisector partial equilibrium framework to simulate the world market for maize and bioethanol. Second, we evaluate the impact of China's bioethanol policies on maize and food security strategies (basic self-sufficiency of cereals) within China, which is of great significance for energy and food security policy making.

The remainder of this paper is organized as follows. The next section reviews the background of China's bioethanol policy. Section 3 introduces the framework, data, and parameters of the world maize supply-demand model. Section 4 describes the policy scenarios, and Sect. 5 analyzes the simulation results. We discuss the findings and highlight the limitations in Sect. 6. Finally, conclusions and policy implications are provided in Sect. 7.

\section{Evolution of bioethanol policy in China}

\subsection{Stage I: 2001-2007}

China initiated its bioethanol program in 2001 when the country had an excess of stale cereals in its national reserve (Zhang, 2015). In "the 10th Five-Year Plan" (2001-2005) made in 2001, the Chinese government began to develop bioethanol gasoline for automobiles. Then, a "Special Plan for the Development of Fuel Ethanol and Ethanol Gasoline for Vehicles during the 10th Five-Year Plan Period" was issued in 2002. Five cities in Henan and Heilongjiang provinces were selected to use a mixture of gasoline $(90 \%)$ and ethanol (10\%), i.e., E10. Since 2004, China has been developing maize-to-ethanol pilot programs, covering 18 cities and 5 counties within 11 provinces (Shan et al., 2016). To further encourage the development of liquid biofuels, the Renewable Energy Law was adopted in 2005. During 2006 and 2007, a series of financially supporting policies were enacted to encourage the development of the biofuel industry. Under policy support, four cereal-based plants and one cassava-based bioethanol plants were built, and the annual growth rate of China's bioethanol production from 2001 to 2007 reached 14.5\% (OECD/FAO, 2021).

\subsection{Stage II: 2007-2016}

With the global food crisis starting in 2007, the Chinese government began to limit the development of cereal-based bioethanol production. The National Development and Reform Commission (NDRC) issued the "Guidance on Promoting the Healthy Development of the Maize DeepProcessing Industry" (the "Limitation Policy") to limit the proportion of processing to domestic demand (PPDD) to $26 \%$ in 2007. Then, in 2008, the "National Framework for Medium-to-Long-Term Grain Security (2008-2020)" was enacted to strictly control the development of cereal-based bioethanol industries. Since then, none of the cereal-based bioethanol plants could be built without the permission of the State Council. As a result, the annual growth rate of China's bioethanol production from 2007 to 2016 dropped to $3.33 \%$ (OECD/FAO, 2021).

\subsection{Stage III: $2016-2020$}

During the 2007-2008 global food crisis, a temporary storage program (TSP) for maize was initiated in 2008 to support domestic production, which led to a rapid increase in maize stocks (Huang et al., 2017). Government notices were issued to support maize-processing enterprises at the provincial level in purchasing temporarily stored maize through subsidies (Huang et al., 2017; Lopez et al., 2017; OECD, 2017). With the supply-side structural reforms in agriculture, the Chinese government has gradually increased its support for the maize-processing industry, including the maizebased bioethanol industry. In 2017, the NDRC announced the "Expansion of Bioethanol Production and Promotion", which set a goal of achieving nationwide use of E10 by 2020 (Macke, 2017). In 2018, more than $125 \mathrm{mmt}$ of cereal (mainly maize) stocks were reduced (Chen, 2020). However, under the uncertainty of the food security situation caused by COVID-19, the Chinese government suspended the implementation of the "Expansion of Bioethanol Production and Promotion" and released a white paper entitled "China's Energy Development in the New Era" in 2020, which limited the development of cereal-based bioethanol production.

\subsection{Future trend}

The history of China's bioethanol policy shows that food security takes priority over the development of bioethanol. The strategic goal of food security in China has been 
to ensure basic self-sufficiency of cereals and absolute security of food grains (Han, 2020). Projections from the USDA (2021a) and OECD/FAO (2021) suggest that China can achieve the goal of absolute security of food grains. Sheng and Song (2019) show that China is projected to be a net exporter of rice and wheat by 2050 . Thus, ensuring the basic self-sufficiency of cereals becomes essential to China's food security strategy. The Chinese government would limit the development of the maize-based bioethanol industry if imports of maize rapidly increase. However, China has formally declared in its nationally determined contributions to hit peak emissions before 2030 (Fang et al., 2019), and bioethanol is still a policy option. Thus, the Chinese government will support the maizebased bioethanol industry if food security is under control. Therefore, China's future bioethanol policy will be flexible, and it is important to provide simulations of the impacts of different bioethanol policies on food security to policymakers to avoid frequent policy changes.

\section{Framework}

\subsection{Study design}

To evaluate the effects of China's bioethanol policy on maize markets and China's food security strategy by 2030, an equilibrium model would be more appropriate. Theoretically, a bioethanol policy would affect the equilibrium prices of maize and bioethanol by shifting the demand and production curves. Meanwhile, consumer and producer welfare are altered accordingly. Then, the price effect of maize will transfer to other agricultural products. On the one hand, because maize is the most important feed source, the price of livestock products will be affected by the change in expenses. On the other hand, there are substitution-related effects among the prices of maize, rice, wheat, and other coarse grains. To simplify the questions and focus on the goal of basic self-sufficiency of cereals, we evaluate the direct effects based on a partial equilibrium model.

According to the basic ideas of treatment effect analysis, we first simulate the scenario under which the Chinese government limits the production of bioethanol (hereafter the "control scenario"). Then, we simulate another scenario that cancels the limitation (hereafter the "treatment scenario"), ceteris paribus. The differences between the simulation results of the control and treatment scenarios indicate the effect of China's bioethanol policy on maize markets and food security.

\subsection{Model framework}

Partial equilibrium models consider one or more commodity markets in isolation from the rest of the economy (Hoang \& Meyers, 2015). A multicountry and multisector partial equilibrium model assumes that the world consists of several countries/regions with each having one or more sectors (Sheng \& Song, 2019). For agricultural sectors, a multicountry and multisector partial equilibrium model assumes that production is determined by technical progress, the quantity of agricultural inputs, and prices of crops. Demand is determined by prices and income. Equilibrium is achieved when the market of every sector in every country/region is synchronously cleared.

Based on the theory of multicountry and multisector partial equilibrium and the basic framework of the International Food and Agricultural Policy Simulation Model (IFPSIM) from the Japan International Research Center for Agricultural Sciences (JIRCAS) (Oga \& Yanagishima, 1995), we build a world maize supply-demand model. Figure 1 shows that the framework has two sectors, maize and bioethanol. In addition to China, other countries in the model include the main maize-importing and maizeexporting countries/regions (the United States, Argentina, Brazil, Ukraine, India, Russia, Japan, South Korea, Mexico, the European Union, and the rest of the world) and the main bioethanol-producing countries/regions (the United States, Brazil, India, the European Union, and the rest of the world). The specific equations of the world maize supply-demand model are shown as follows.

\subsubsection{Production equations}

Maize production is determined by the area planted and yield, while bioethanol production is determined by the consumer prices of crude oil, maize and bioethanol (Birur et al., 2008; Haile et al., 2014).

$$
\begin{aligned}
& Q C N_{i}=A A_{i} \times Y D_{i} \\
& \ln A A_{i}=\alpha_{A A, i}+\sum_{j} e_{P P D, i, j}^{A A} \ln P P D_{i, j}+e_{F E R}^{A A} \ln P F E R_{i} \\
& Y D_{t, i}=\alpha_{Y D, i}+Y D_{t-1, i} \times\left(1+T E C H_{i}\right) \\
& \ln Q B E_{k}=\alpha_{Q B E, k}+\sum_{l} e_{P C S, k, l}^{Q B E} \ln P C S_{k, l}
\end{aligned}
$$

where $Q C N$ and $Q B E$ are the production of maize and bioethanol, respectively; $A A$ is the area planted; $Y D$ is the 


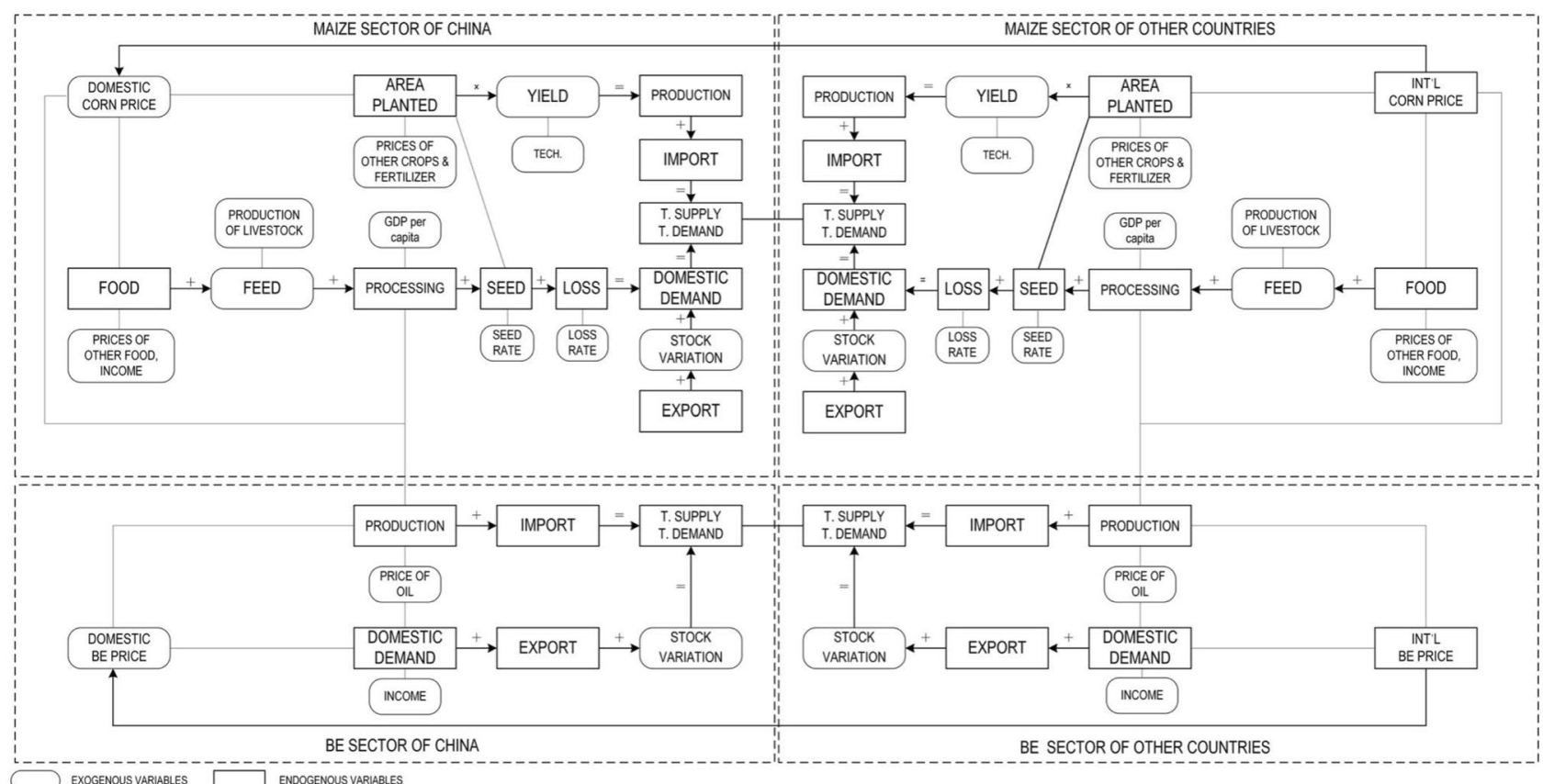

Fig. 1 Framework of the world maize supply-demand model. BE=bioethanol, T. SUPPLY=total supply, T. DEMAND=total demand, $\mathrm{TECH}=$ technological progress, INT'L $=$ international, SEED RATE $=$ seed usage per area planted

yield; $P P D, P C S$, and PFER are the producer, consumer, and fertilizer prices, respectively; TECH is the rate of technological progress; $\alpha$ and $e$ are the intercept and elasticity, respectively; and $i, j, k, l$, and $t$, respectively, represent the countries of the maize sector, various crops (i.e., rice, wheat, maize, soybean and other cereals), the countries of the bioethanol sector, various goods (i.e., oil, maize and bioethanol) and the time variable.

\subsubsection{Domestic demand equations}

The equations for the domestic demands of maize and bioethanol are as follows:

$D D C N_{i}=F O O D_{i}+F E E D_{i}+P_{R O C}+S E E D_{i}+L_{i} O S S_{i}+S T V_{i}$

$\ln D D B E_{k}=\alpha_{D D B E, k}+\sum_{n} e_{P C S, k, n}^{D D B E} \ln P C S_{k, n}+e_{P G D P, k}^{D D B E} \ln P G D P_{k}$

where DDCN, FOOD, FEED, PROC, SEED, LOSS, and $S T V$ are the domestic demand, food demand, feed demand, processing demand, seed demand, loss, and stock variation for maize, respectively. $D D B E$ is the domestic demand for bioethanol. PCS indicates the consumer prices of oil and bioethanol and $P G D P$ is the GDP per capita.
$F O O D_{i}=\mathrm{PFOOD}_{i} \times \mathrm{POP}_{i}$

$\ln$ PFOOD $_{i}=\alpha_{F P O O D, i}+\sum_{j} e_{P C S, i, j}^{P F O O D} \ln P C S_{i, j}+e_{P G D P, i}^{P F O O D} \ln P G D P_{i}$

The food demand for maize (FOO is determined by multiplying per capita consumption $(P F O O D)$ by the total population $(P O P)$. Following (Deaton \& Muellbauer, 1980), the factors that affect per capita consumption include elasticities for income, own-price, and cross-price. In this paper, we use per capita GDP $(P G D P)$ as the proxy for income.

$F E E D_{i}=\alpha_{F E E D, i}+\delta_{R L S C N, i, m}^{L S} \times L S_{i, m}$

The feed demand (FEED) is determined by the production of livestock products $(L S)$ and the conversion ratio between livestock products and maize $\left(\delta_{R L S C N}^{L S}\right)$.

$P R O C_{i}=\alpha_{P R O C, i}+\delta_{R B E C N, i} \times \delta_{B E C N, i} \times Q B E_{i}+\exp \left(e_{P G D P P T}^{P R O C R} \times \ln P G D P_{i}\right)$

The processing demand of maize $(P R O C)$ is the sum of the bioethanol processing and other processing demands. The bioethanol-processing demand is a function of bioethanol production $(Q B E)$, the conversion ratio between bioethanol and maize $\left(\delta_{R L S C N}^{L S}\right)$ and the proportion of maizebased bioethanol production to total bioethanol production 
$\left(\delta_{B E C N}\right)$. The other processing demand is a function of per capita GDP.

$S E E D_{i}=\alpha_{S E E D, i}+R S E E D_{i} \times A A_{i}$

$S T V_{i}=A S T V_{i}$

LOSS $_{i}=$ RLOSS $_{i} \times\left(F O O D_{i}+F E E D_{i}+\right.$ PROC $\left._{i}+S E E D_{i}+S T V_{i}\right)$

The seed demand (SEED) is determined by multiplying the seed usage per area planted (RSEED) by the area planted $(A A)$. Since it is impossible to obtain official data on the maize stock in China, the stock variation $(S T V)$ is set as an exogenous variable (ASTV). Loss is determined by multiplying the loss rate (RLOSS) by the quantity of other domestic demands.

\subsubsection{Price linkage equations}

Let the international maize price be $W P C N$. The unit is USD, and the consumer price (PCSCN) and producer price $(P P D C N)$ of maize in country $i$ are given by the following equations:

$$
\begin{aligned}
& \operatorname{PCSCN}_{i}=W P C N \times \operatorname{EXCH}_{i} \times\left(1+T R F_{i}\right) \\
& \operatorname{PPDCN}_{i}=\operatorname{PCSCN}_{i}+M_{i} \times \mathrm{EXCH}_{i}
\end{aligned}
$$

where $E X C H$ is the exchange rate, $T R F$ is the tariff rate, and $M M$ is the market margin.

Similarly, the price of bioethanol $(P B E)$ in country $k$ is determined by the international bioethanol price $(W P B E)$ and the exchange rate.

$P B E_{k}=W P B E \times E X C H_{k}$

\subsubsection{Trade equations}

Assume that there is $a$, a net maize-exporting country and $b$, a net bioethanol-exporting country. The net export quantities in countries $a$ and $k$ are the differences between domestic production and demand, while the net import quantities in countries $i-a$ and $k-b$ are the differences between domestic demand and production.

$$
\begin{aligned}
& \operatorname{NEXCN}_{a}=Q C N_{a}-D D C N_{a} \\
& \operatorname{NEXBE}_{k}=Q B E_{k}-D D B E_{k} \\
& \operatorname{NIMCN}_{i-a}=D D C N_{i-a}-Q C N_{i-a}
\end{aligned}
$$

$N I M B E_{k-b}=D D B E_{k-b}-Q B E_{k-b}$

\subsubsection{Constraints}

The model has four homogeneous constraints, measured by the sum of the elasticities, which are all zero: (1) producer prices to the area planted, (2) consumer prices to food consumption, (3) prices to bioethanol production, and (4) prices to bioethanol consumption. Furthermore, the proportion of processing to domestic demand (PPDD) in China was limited to $26 \%$ by the "Limitation Policy". Since the NDRC bioethanol promotion policy in 2017, the PPDD has been larger than 26\% and reached approximately $32 \%$ in 2019 (Chinese Academy of Agricultural Sciences, 2021). To simulate the policy constraints, we assume that the upper limit of the proportion of the processing demand in domestic production remains at the level of $32 \%$ in the control scenarios.

$\sum_{j} e_{P P D, i, j}^{A A}=0, \sum_{l} e_{P C S, k, l}^{Q B E}=0, \sum_{j} e_{P C S, i, j}^{P F O O D}=0, \sum_{n} e_{P C S, k, n}^{D D B E}=0$

PROC $_{\text {CHINA }}=Q C N_{\text {CHINA }} \times 32 \%$, if PROC $C_{C H I N A}>\left(Q C N_{\text {CHINA }} \times 32 \%\right)$

\subsubsection{Market clearing}

Based on the above equations, we can obtain the total supply and total demand of maize and bioethanol in every country/ region. When the maize and bioethanol markets in every country/region are clearing simultaneously, the total production of maize/bioethanol should be equal to the total demand for maize/bioethanol. In this paper, this condition can be given as follows:

$\sum_{a} N E X C N_{a}=\sum_{i-a} \operatorname{NIMCN}_{i-a}$

$\sum_{b} N E X B E_{b}=\sum_{k-b} N I M B E_{k-b}$

\subsubsection{Producer and consumer surplus}

Assuming the production and demand curves remain the same (though Eq. 22 changes the demand curve), the increase of producer price increases from $P_{1}=P P D C N_{1}$ to $P_{2}=P P D C N_{2}$ leads to the change in producer surplus $(\triangle P S)$ and the increase of consumer price increases from $P_{1}^{*}=P C S C N_{1}$ to $P_{2}^{*}=\operatorname{PCSCN}_{2}$ leads to the change in consumer surplus $(\triangle C S)$. Under Eq. 15, we can calculate the change in overall economic surplus $(\Delta E S)$. Due to the use of 
price indexes instead of prices in the PE model, we calculate the changes in overall economic surplus as a percentage.

$\Delta E S \%=\frac{\Delta P S+\Delta C S}{P S_{0}+C S_{0}} \times 100 \%$

$\Delta P S=\int_{P_{1}}^{P_{2}} Q C N(P) \mathrm{d} P$

$P S_{0}=\int_{0}^{P_{1}} Q C N(P) \mathrm{d} P$

$\Delta C S=-\int_{P_{1}^{*}}^{P_{2}^{*}} D D C N(P) \mathrm{d} P$

$C S_{0}=-\int_{0}^{P_{1}^{*}} D D C N(P) \mathrm{d} P$

\subsection{Data}

The maize production and trade data of China are mainly obtained from the NBSC and the General Administration of Customs of China, respectively. The maize demand data of China are calculated following the method of Chen (2004) and Han (2019). The production, demand, and trade data of maize for other countries are obtained from the food balance sheets of the FAO (FAO, 2018), while the complete bioethanol data sets are obtained from the OECD-FAO Agricultural Outlook (OECD/FAO, 2021). The base year of the world maize supply-demand model is 2016 (see "electronic supplementary material 1 -balance sheets") and the projection period is $2017-2030$.

\subsection{Parameters and calibration}

The elasticities of maize production and food demand in China are the median of previous studies (Han, 2019), while those of other countries are obtained from Meade et al. (2014) and Oga and Yanagishima (1995). The conversion ratios between livestock products and maize are taken from Oga and Yanagishima (1995), while the seed usage per area planted and the loss rate are the historical means between 1993 and 2016 (Han, 2019). The elasticities of bioethanol production and demand were obtained from Han (2019). The intercept terms were obtained from the calibration process to be consistent with the given data above. All the parameters are reported in the "electronic supplementary material 2-parameters". The equations are written in R and solved with Newton's iteration method following Peng (2009).

\section{Scenarios}

\subsection{Baseline scenarios}

In the baseline scenarios, we assume that the macroeconomy grows at a normal level. (1) Annual growth of GDP per capita. As projected by the USDA, the OECD-FAO, and the U.S. Census Bureau, the annual growth of GDP per capita in China is assumed to decline in the next decade. We assume that the annual growth of GDP per capita in China will be $4.0 \%$ and $3.2 \%$ in 2025 and 2030, respectively. (2) Annual growth of population. The total population of China is projected to reach 1.42 billion in 2030 (United Nations, 2015). (3) Exchange rate. The USD is expected to appreciate the Chinese RMB before 2030 to reach 5.59 RMB per USD in 2030. (4) Other exogenous variables. The projections of exogenous prices, stock variation, and livestock production are obtained from the OECD-FAO Agricultural Outlook (OECD/FAO, 2021) (see "electronic supplementary material 3-exogenous variables under baseline scenario").

There are two subscenarios in the baseline scenarios. To simulate the impacts of China's bioethanol promotion on the global maize market, we first set a baseline control scenario (limitation of maize-processing). In the baseline control scenario, we keep the constraint in Eq. 22 and assume that the NDRC strictly limits the development of bioethanol.

Then, in the baseline treatment scenario (free development of bioethanol with normal-speed growth), we ignore Eq. 22 and assume that the bioethanol industry can be developed freely in China, and the annual growth of the exogenous variables is the same as that in the baseline control scenario. The difference in the simulation results between the baseline control scenario and baseline treatment scenario is the "strategy space" for the policy makers of the central government.

\subsection{High scenarios}

In the high scenarios, we assume that the macroeconomy grows at a high level. To simulate an extreme situation standing for high-speed growth, the annual growth of the exogenous variables is assumed to be 1 percentage point more than that of the baseline scenarios (see "electronic supplementary material 4-exogenous variables under high scenario"). There are two subscenarios. In the high control scenario, the NDRC strictly limits the development of bioethanol, while the bioethanol industry can be developed freely in the high treatment scenario. 
Table 1 Sensitivity check of the baseline control scenario for the world maize supply-demand model

\begin{tabular}{llll}
\hline & $\begin{array}{l}\text { Deviation in world } \\
\text { maize price in 2030 }\end{array}$ & $\begin{array}{l}\text { Deviation in China's } \\
\text { maize production in } \\
2030\end{array}$ & $\begin{array}{l}\text { Deviation in China's } \\
\text { maize demand in } \\
2030\end{array}$ \\
\hline All parameters increase by 1\% & $0 \%$ & $0 \%$ & $0 \%$ \\
All parameters increase by 5\% & $0 \%$ & $1 \%$ & $1 \%$ \\
All parameters increase by 10\% & $-1 \%$ & $1 \%$ & $1 \%$ \\
All parameters decrease by 1\% & $0 \%$ & $0 \%$ & $0 \%$ \\
All parameters decrease by 5\% & $0 \%$ & $-1 \%$ & $-2 \%$ \\
All parameters decrease by 10\% & $-2 \%$ & $-2 \%$ & $-5 \%$ \\
\hline
\end{tabular}

\subsection{Low scenarios}

Contrary to the high scenarios, the macroeconomy is set to grow at a low level. The annual growth of the exogenous variables is assumed to be 1 percentage point less than that of the baseline scenarios (see "electronic supplementary material 5-exogenous variables under low scenario"). We also set two subscenarios: a low control scenario (limitation of maize-processing) and a low treatment scenario (free development of bioethanol).

\section{Simulation results}

We first check the sensitivity of the model by setting all parameters to increase/decrease by $1 \%, 5 \%$, and $10 \%$. The results show that the model is robust to small deviations in the parameter values (Table 1). Across the parameter sensitivity tests, the maximum deviation in the projection of the main endogenous variables is less than $5 \%$.

Table 2 Simulation results for the world maize supply-demand model: baseline scenarios

\begin{tabular}{|c|c|c|c|c|c|}
\hline & $\begin{array}{l}2016 \\
\text { Base year } \\
\text { (1) }\end{array}$ & $\begin{array}{l}2030 \\
\text { Baseline control } \\
\text { (2) }\end{array}$ & $\begin{array}{l}2030 \\
\text { Baseline treatment } \\
\text { (3) }\end{array}$ & $\begin{array}{l}2030 \\
\text { Diff. } \\
(4)=(3)-(2)\end{array}$ & $\begin{array}{l}2030 \\
\text { Diff. }(\%) \\
(5)=(4) /(2)\end{array}$ \\
\hline \multicolumn{6}{|l|}{ Maize } \\
\hline $\begin{array}{l}\text { World price index } \\
\text {-CHINA }\end{array}$ & 100 & 170 & 178 & 8 & 5 \\
\hline -Producer price index & 100 & 172 & 181 & 9 & 5 \\
\hline -Consumer price index & 100 & 170 & 178 & 8 & 5 \\
\hline -Production (mmt) & 264 & 307 & 309 & 2 & 1 \\
\hline -Area planted (million HA) & 44 & 46 & 46 & 0 & 1 \\
\hline -Domestic demand (mmt) & 267 & 314 & 335 & 21 & 7 \\
\hline -Food demand (mmt) & 6 & 6 & 6 & 0 & -1 \\
\hline -Processing demand (mmt) & 61 & 101 & 122 & 21 & 21 \\
\hline$-\operatorname{PPDD}(\%)$ & 23 & 32 & 36 & 4 & 13 \\
\hline -Feed demand (mmt) & 157 & 194 & 194 & 0 & 0 \\
\hline -Seed demand (mmt) & 1 & 1 & 1 & 0 & 2 \\
\hline$-\operatorname{Loss}(\mathrm{mmt})$ & 11 & 11 & 11 & 0 & 0 \\
\hline -Net imports (mmt) & 3 & 7 & 26 & 19 & 256 \\
\hline -Self-sufficiency ratio (\%) & 99 & 98 & 92 & -6 & -6 \\
\hline \multicolumn{6}{|l|}{ Bioethanol } \\
\hline $\begin{array}{l}\text { World price index } \\
\text {-CHINA }\end{array}$ & 100 & 159 & 165 & 6 & 4 \\
\hline -Production (million liters) & 9400 & 11,292 & 15,088 & 3796 & 34 \\
\hline -Domestic demand (million liters) & 9900 & 12,260 & 16,370 & 4110 & 34 \\
\hline -Net imports (million liters) & 757 & 968 & 1282 & 314 & 33 \\
\hline
\end{tabular}




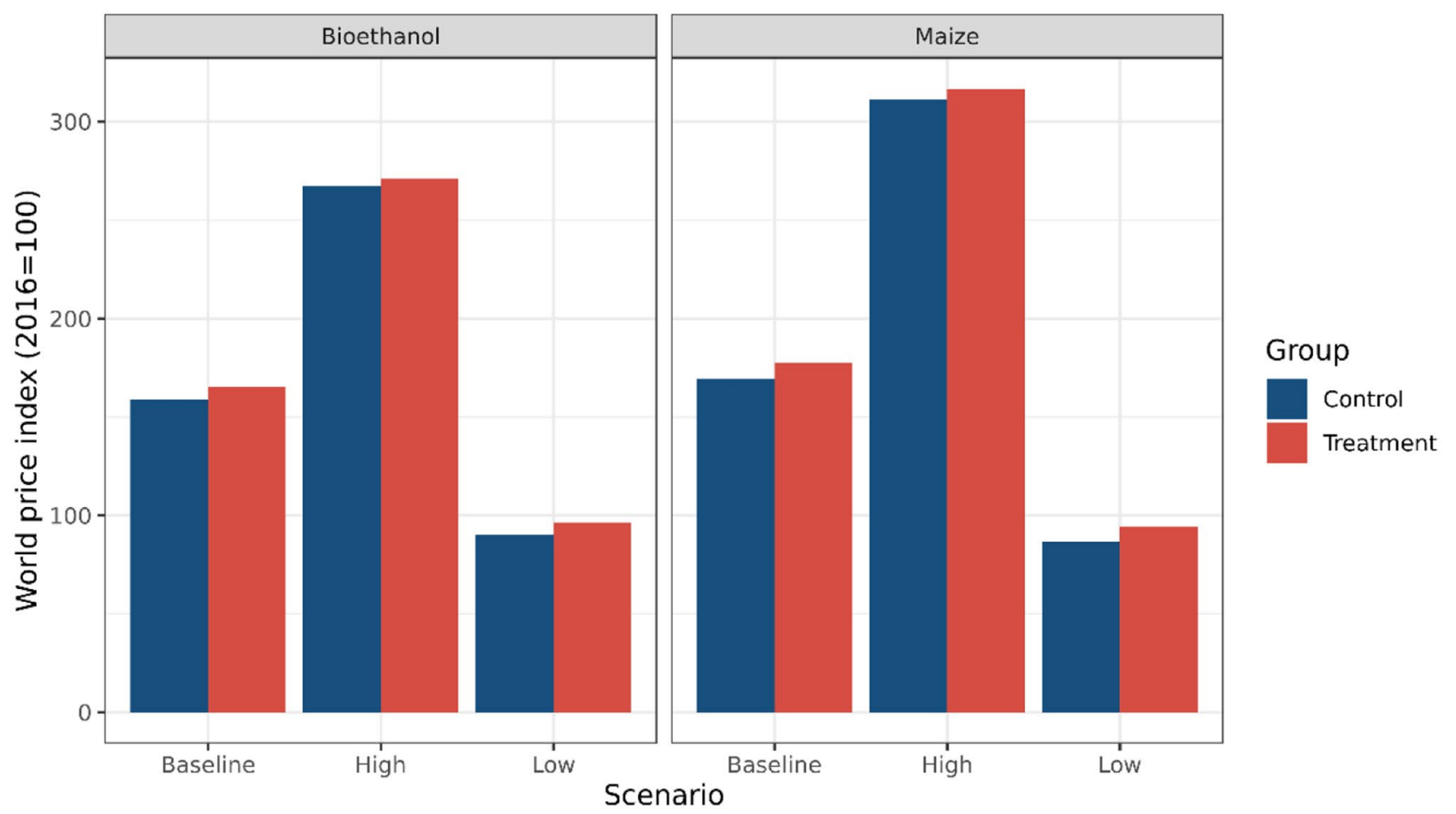

Fig. 2 World price indexes of maize and bioethanol in 2030

\subsection{Baseline scenarios}

The baseline scenario projections are shown in Table 2. As discussed above, the policy concerning the maize-processing industry in China is quite flexible. If the Chinese government is concerned about the impact of bioethanol policy on food security and issues macrocontrol policies to limit the proportion of the processing of the domestic demand (PPDD) to $32 \%$ (baseline control scenario), China will net import $7 \mathrm{mmt}$ of maize in 2030. Furthermore, the world maize price index will reach $170(2016=100)$ in 2030 (column 2, Table 2).

Specifically, by 2030 , the maize-planted area is projected to reach 46 million hectares, and China will produce $307 \mathrm{mmt}$ of maize, which is $16 \%$ more than the amount in the base year (column 1, Table 2). Meanwhile, the yield is expected to be $6671 \mathrm{~kg} / \mathrm{ha}$ in 2030, which is approximately 12\% higher than the yield in 2016 (see "electronic supplementary material 6-simulation results-baseline scenarios"). The results imply that, without further support of yield growth, China will import much more maize in the future under this scenario. Meanwhile, the domestic and processing demands will be $18 \%$ and $66 \%$, respectively, greater than these demands in the base year.

The world bioethanol price index will be $159(2016=100)$ in 2030. China's bioethanol production is projected to increase from 9400 million liters in 2016 to 11,292 million liters in 2030. Meanwhile, the bioethanol demand of China will increase to 12,260 million liters in 2030 .

Assume that maize processing and the bioethanol industry can be developed freely in China as a result of the bioethanol promotion policy with economic growth proceeding normally in the following decade (column 3, Table 2). Under the baseline treatment scenario, net imports of maize in China will reach $26 \mathrm{mmt}$ in 2030, which is $19 \mathrm{mmt}$ or $256 \%$ higher than that of the baseline control scenario (columns 4 and 5, Table 2). This result implies that China's bioethanol promotion policy would cause China to become one of the largest maize-importing countries in the world. Meanwhile, the ratio of self-sufficiency would drop to $92 \%$ in 2030, which is approximately $5 \%$ points less than that of the baseline control scenario. This indicates that China's policymakers will find it challenging to achieve basic selfsufficiency in cereal grains.

Furthermore, the world maize price index is estimated to increase by $5 \%$ in 2030 compared with the price index of the baseline control scenario, while the world bioethanol price index will increase by $4 \%$ in 2030 compared with the price index of the baseline control scenario (column 5, Table 2). Based on Eqs. 25-29, we calculate the changes in economic surplus caused by the price change. The results show that an increase in price leads to an increase of $3 \%$ in overall economic surplus. It indicates that the development of the bioethanol industry is expected to benefit the economy. 
Table 3 Simulation results for the world maize supply-demand model: high scenarios

\begin{tabular}{|c|c|c|c|c|c|}
\hline & $\begin{array}{l}2016 \\
\text { Base year } \\
\text { (1) }\end{array}$ & $\begin{array}{l}2030 \\
\text { High control } \\
\text { (2) }\end{array}$ & $\begin{array}{l}2030 \\
\text { High treatment } \\
\text { (3) }\end{array}$ & $\begin{array}{l}2030 \\
\text { Diff. } \\
(4)=(3)-(2)\end{array}$ & $\begin{array}{l}2030 \\
\text { Diff. (\%) } \\
(5)=(4) /(2)\end{array}$ \\
\hline \multicolumn{6}{|l|}{ Maize } \\
\hline $\begin{array}{l}\text { World price index } \\
\text {-CHINA }\end{array}$ & 100 & 311 & 317 & 6 & 2 \\
\hline -Producer price index & 100 & 319 & 325 & 6 & 2 \\
\hline -Consumer price index & 100 & 311 & 317 & 6 & 2 \\
\hline -Production (mmt) & 264 & 330 & 331 & 1 & 0 \\
\hline -Area planted (million HA) & 44 & 49 & 50 & 1 & 0 \\
\hline -Domestic demand (mmt) & 267 & 385 & 394 & 9 & 2 \\
\hline -Food demand (mmt) & 6 & 6 & 6 & 0 & 0 \\
\hline -Processing demand (mmt) & 61 & 124 & 133 & 9 & 8 \\
\hline -PPDD (\%) & 23 & 32 & 34 & 2 & 5 \\
\hline -Feed demand (mmt) & 157 & 243 & 243 & 0 & 0 \\
\hline -Seed demand (mmt) & 1 & 1 & 1 & 0 & 1 \\
\hline -Loss (mmt) & 11 & 11 & 11 & 0 & 0 \\
\hline -Net imports (mmt) & 3 & 55 & 64 & 9 & 15 \\
\hline -Self-sufficiency ratio (\%) & 99 & 86 & 84 & -2 & -2 \\
\hline \multicolumn{6}{|l|}{ Bioethanol } \\
\hline $\begin{array}{l}\text { World price index } \\
\text {-CHINA }\end{array}$ & 100 & 267 & 271 & 4 & 2 \\
\hline -Production (million liters) & 9400 & 13,640 & 13,583 & -57 & 0 \\
\hline -Domestic demand (million liters) & 9900 & 14,913 & 14,854 & -59 & 0 \\
\hline -Net imports (million liters) & 757 & 1272 & 1272 & 0 & 0 \\
\hline
\end{tabular}

Full results can be found in the "electronic supplementary material 7-simulation results—high and low scenarios"
On the production side, the planted area in China would be $1 \%$ higher than that of the baseline control scenario. On the demand side, the fast growth of bioethanol will result in a rapid increase in the processing demand. Without a limitation policy, China's bioethanol production will be 15,088 million liters in 2030, which is $34 \%$ higher than that of the baseline control scenario. As a result, the maize processing demand in 2030 is $21 \%$ higher than that of the baseline control scenario. The ratio of the processing demand to domestic production will increase to $36 \%$ in 2030 . These results imply that China's bioethanol promotion policy will boost the processing demand of maize and that maize will become a crucial feedstock for the energy industry in China.

\subsection{High scenarios}

In high scenarios, the simulated results show that the world maize price index and world bioethanol price index in 2030 are projected to be much higher than those of the baseline scenarios (Fig. 2). China's net import of maize will increase to 55-64 mmt in 2030 (columns 2 and 3, Table 3). The boost in net imports comes from the faster increase in maize demand. Moreover, the ratio of the self-sufficiency of maize in China will drop to 84-86\% in 2030 (columns 2 and 3 , Table 3). It is a signal that production growth could not match demand growth, and China won't be able to achieve its policy objective of ensuring basic self-sufficiency in cereals, if the government stock could not be released to the market. However, we use the high scenarios to present a potential upper limit of China's net import of maize because it is difficult to make all exogenous variables grow one percentage point faster annually in the real world.

Under high-speed growth, the impacts of China's bioethanol policy on maize markets can be drawn from the differences between the results of the high treatment scenario and high control scenario (columns 4 and 5, Table 3). In the high treatment scenario, the world maize price index and world bioethanol price index in 2030 are projected to be $2 \%$ higher than those of the high control scenario (column 5, Table 3). Moreover, the ratio of the self-sufficiency of maize in China will be $2 \%$ point lower than that of the high control scenario in 2030. In 2030, China's maize production and domestic demand will reach 331 and $394 \mathrm{mmt}$, respectively, which are $1 \mathrm{mmt}$ and $9 \mathrm{mmt}$ higher, respectively, than the results in the high control scenario. In terms of demand, China's processing demand for maize will be $8 \%$ higher in 2030 than in the 
Table 4 Simulation results for the world maize supply-demand model: low scenarios

\begin{tabular}{llllll}
\hline & 2016 & 2030 & 2030 & 2030 & 2030 \\
& Base year & Low control & Low treatment & Diff. & Diff. (\%) \\
& $(1)$ & $(2)$ & $(3)$ & $(4)=(3)-(2)$ & $(5)=(4) /(2)$ \\
\hline Maize & & & & & \\
World price index & 100 & 87 & 94 & 7 & 8 \\
-CHINA & & & & & \\
-Producer price index & 100 & 86 & 94 & 8 & 9 \\
-Consumer price index & 100 & 87 & 94 & 7 & 8 \\
-Production (mmt) & 264 & 282 & 285 & 3 & 1 \\
-Area planted (million HA) & 44 & 42 & 43 & 1 & 1 \\
-Domestic demand (mmt) & 267 & 251 & 284 & 33 & 13 \\
-Food demand (mmt) & 6 & 6 & 6 & 0 & -1 \\
-Processing demand (mmt) & 61 & 81 & 113 & 32 & 40 \\
-PPDD (\%) & 23 & 32 & 40 & 8 & 24 \\
-Feed demand (mmt) & 157 & 152 & 152 & 0 & 0 \\
-Seed demand (mmt) & 1 & 1 & 1 & 0 & 3 \\
-Loss (mmt) & 11 & 11 & 11 & 0 & 0 \\
-Net imports (mmt) & 3 & -30 & -2 & 28 & -95 \\
-Self-sufficiency ratio (\%) & 99 & 112 & 101 & -11 & -10 \\
Bioethanol & & & & & -2 \\
World price index & 100 & 90 & 96 & 6 & 7 \\
-CHINA & 9400 & 17,321 & 16,991 & -330 & -321 \\
-Production (million liters) & 9900 & 18,569 & 18,248 & 9 & -2 \\
-Domestic demand (million liters) & 757 & 1248 & 1257 & & \\
-Net imports (million liters) & & & & & \\
\hline & & & & & \\
\hline
\end{tabular}

Full results can be found in the "electronic supplementary material 7-simulation results—high and low scenarios" high control scenario, but bioethanol production will be 57 million liters less in 2030 than in the high control scenario. The results indicate that if there is no limitation on PPDD, the maize processing industry would like to develop much faster than the maize-to-ethanol industry under high-speed growth.

\subsection{Low scenarios}

Low scenario simulations indicate that the world maize price index and the world bioethanol price index in 2030 will be significantly lower than those of baseline scenarios (Fig. 2). China is likely to be a net exporter by 2030, with its net exports estimated to be between 2 and $30 \mathrm{mmt}$ (columns 2 and 3, Table 4). Furthermore, it is estimated that China's self-sufficiency in maize is expected to reach 101-112\% 100\% by 2030 (columns 2 and 3, Table 4). The results indicate that if the world and China decelerate their development engines, China could ensure food security. Likewise, the low scenarios are used as a potential lower limit to China's net import of maize because it may be difficult in the real world to make all exogenous variables increase one percentage point less annually.

The differences between the results of the low treatment and low control scenarios provide information about the impact of China's bioethanol policy on maize markets under lowspeed growth (columns 4 and 5, Table 4). According to the low treatment scenario, the world maize price index and the world bioethanol price index in 2030 are expected to be $8 \%$ and $7 \%$ higher than those in the low control scenario, respectively (column 5, Table 4). By 2030, China's maize production and domestic demand will reach $285 \mathrm{mmt}$ and $284 \mathrm{mmt}$, respectively, which represents a $1 \%$ and $13 \%$ increase from the results in the low control scenario. China's processing demand for maize is projected to be $40 \%$ higher in 2030 than in the low control scenario, but its bioethanol output is projected to be $2 \%$ lower in 2030 than in the low control scenario. Results indicate that if PPDD were not restricted, the maize processing industry would probably develop more rapidly than the maizeto-ethanol sector under low-speed growth. 
Table 5 Maize imports and exports of major counties in 2030

\begin{tabular}{llllll}
\hline Scenarios & \multirow{2}{*}{\begin{tabular}{l} 
Net imports \\
\cline { 3 - 6 }
\end{tabular}} & China & USt exports & \\
\cline { 3 - 6 } & & Brazil & Argentina & Ukraine \\
\hline Baseline control & 7 & 88 & 20 & 14 & 28 \\
Baseline treatment & 26 & 95 & 21 & 16 & 28 \\
High control & 55 & 126 & 22 & 20 & 25 \\
High treatment & 64 & 129 & 23 & 21 & 25
\end{tabular}

\section{Discussion}

The projections show that if the global economy grows at a normal or high speed, China will import much more maize in the next decade. Considering the bioethanol promotion policy, the quantity of maize imports in China might increase from $3 \mathrm{mmt}$ in 2016 to $26-64 \mathrm{mmt}$ in 2030. Thus, China would likely become one of the largest maize-importing countries in the world and maize would become the second largest imported grain crop in China after soybean. However, under low-speed growth, China could become a net exporter of maize.
The quantity of soybean imports in China has increased from $10 \mathrm{mmt}$ in 2000 to $100 \mathrm{mmt}$ in 2020 due to the rapid growth in livestock production. However, the international soybean market has remained stable since the United States, Brazil, and Argentina can produce enough soybeans to meet the demand from China. Similarly, the world market and domestic policy tools could ensure China's increasing import demand for maize. In our simulations, China's import demand for maize can be satisfied. The major maize-exporting counties have sufficient potential to expand maize production and export. Under baseline control and treatment scenarios, the United States, Brazil, Argentina, and Ukraine are expected to export 88-95 $\mathrm{mmt}, 20-21 \mathrm{mmt}, 14-16 \mathrm{mmt}$, and approximately $28 \mathrm{mmt}$, respectively (Table 5). Additionally, by issuing administrative orders, Chinese policymakers have an effective tool for preventing maize processing from developing too quickly, which will help limit bioethanol production when the ratio of self-sufficiency crosses the chosen tolerance level.

We further designed two extra scenarios to simulate extreme situations. We first set a baseline E10 scenario assuming that the macroeconomy grows at a normal level

Table 6 Simulation results for the world maize supply-demand model: E10 scenario

\begin{tabular}{|c|c|c|c|c|c|}
\hline & $\begin{array}{l}2016 \\
\text { Base year } \\
\text { (1) }\end{array}$ & $\begin{array}{l}2030 \\
\text { Baseline control } \\
\text { (2) }\end{array}$ & $\begin{array}{l}2030 \\
\text { Baseline E10 } \\
\text { (3) }\end{array}$ & $\begin{array}{l}2030 \\
\text { Diff. } \\
(4)=(3)-(2)\end{array}$ & $\begin{array}{l}2030 \\
\text { Diff. (\%) } \\
(5)=(4) /(2)\end{array}$ \\
\hline \multicolumn{6}{|l|}{ Maize } \\
\hline $\begin{array}{l}\text { World price index } \\
\text {-CHINA }\end{array}$ & 100 & 178 & 205 & 28 & 16 \\
\hline -Producer price index & 100 & 181 & 209 & 29 & 16 \\
\hline -Consumer price index & 100 & 178 & 205 & 28 & 16 \\
\hline -Production (mmt) & 264 & 309 & 316 & 7 & 2 \\
\hline -Area planted (million HA) & 44 & 46 & 47 & 1 & 2 \\
\hline -Domestic demand (mmt) & 267 & 335 & 404 & 69 & 21 \\
\hline -Food demand (mmt) & 6 & 6 & 6 & 0 & -2 \\
\hline -Processing demand (mmt) & 61 & 122 & 191 & 69 & 57 \\
\hline$-\operatorname{PPDD}(\%)$ & 23 & 36 & 47 & 11 & 30 \\
\hline -Feed demand (mmt) & 157 & 194 & 194 & 0 & 0 \\
\hline -Seed demand (mmt) & 1 & 1 & 1 & 0 & 5 \\
\hline -Loss (mmt) & 11 & 11 & 11 & 0 & 0 \\
\hline -Net imports (mmt) & 3 & 26 & 88 & 62 & 237 \\
\hline -Self-sufficiency ratio (\%) & 99 & 92 & 78 & -14 & -15 \\
\hline \multicolumn{6}{|l|}{ Bioethanol } \\
\hline $\begin{array}{l}\text { World price index } \\
\text {-CHINA }\end{array}$ & 100 & 165 & 184 & 19 & 12 \\
\hline -Production (million liters) & 9400 & 15,088 & 44,582 & 29,494 & 196 \\
\hline -Domestic demand (million liters) & 9900 & 16,370 & 45,121 & 28,751 & 176 \\
\hline -Net imports (million liters) & 757 & 1282 & 538 & -744 & -58 \\
\hline
\end{tabular}

Full results can be found in the "electronic supplementary material 6- simulation results-baseline scenarios" 
Fig. 3 World price indexes of maize and bioethanol in 2030 under volatility of crude oil price and GDP per capita. Notes: full results can be found in the "electronic supplementary material 6-simulation results-baseline scenarios"

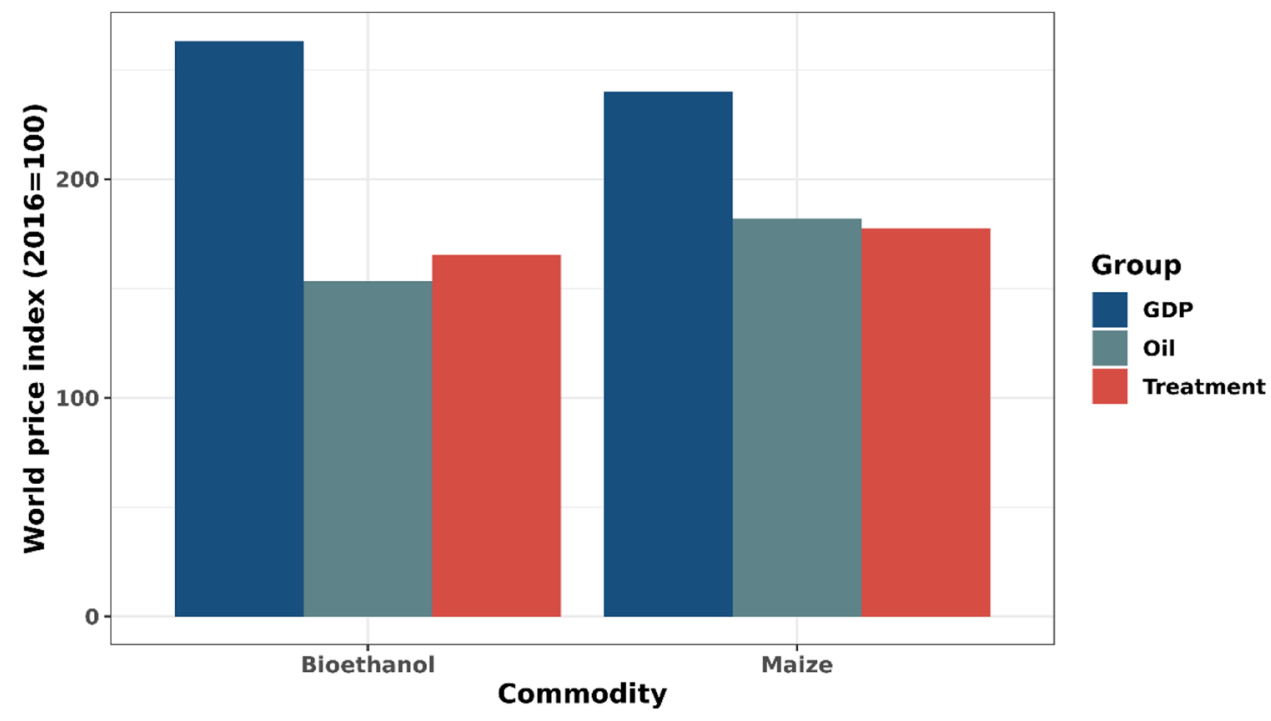

and that the bioethanol industry can be developed freely. China's production of bioethanol in 2030 can meet the demand for nationwide use of E10. According to Feng et al. (2019), gasoline demand in China will reach $356.4 \mathrm{mmt}$ in 2030. Thus, the demand for bioethanol will be $35.6 \mathrm{mmt}$ or 44,551 million liters in 2030. Since China's imports of bioethanol remain at approximately 800 million liters (OECD/FAO, 2021), we assume that China's domestic production of bioethanol will meet the demand, and $70 \%$ of the feedstock of China's bioethanol is maize.

China's production of bioethanol in 2030 will reach 44,582 million liters to meet the demand of nationwide use of E10 (columns 3, Table 6), which is $196 \%$ higher than that of the baseline control scenario. The simulation results in Table 6 show that the world maize price index will be $16 \%$ higher than that of the baseline control scenario, while the world bioethanol price index will be $12 \%$ higher. The increase in China's production of bioethanol has led to the rapid development of the maize processing industry. By 2030, China's maize processing demand will be $191 \mathrm{mmt}$, and the PPDD will increase to $47 \%$. As a result, China's net import of maize will reach $88 \mathrm{mmt}$ in 2030, and the ratio of self-sufficiency will drop to $78 \%$. The results imply that the nationwide use of E10 in China would have a negative impact on food security.

Then, based on the baseline treatment scenario, we estimate the range of China's bioethanol production due to the volatility of crude oil price and GDP per capita (Fig. 3). On the one hand, if crude oil prices in 2030 increase by $100 \%$ based on the baseline treatment scenario, the world maize price index will be $2 \%$ higher than that of the baseline treatment scenario, and the world bioethanol price index will be 7\% lower than that of the baseline treatment scenario. Therefore, China's bioethanol production will decrease by $18 \%$ compared with the results of the baseline treatment scenario. On the other hand, if GDP per capita in 2030 increases by $100 \%$ based on the baseline treatment scenario, the world maize price index and world bioethanol price index will be $35 \%$ and $59 \%$ higher than those of the baseline treatment scenario.
Table 7 Comparison of simulation results across recent studies

\begin{tabular}{lllll}
\hline Source & Target year & $\begin{array}{l}\text { Revised statisti- } \\
\text { cal data }\end{array}$ & Scenario & $\begin{array}{l}\text { Net imports } \\
\text { (million } \\
\text { tons) }\end{array}$ \\
\hline Furuhashi (2015) & 2024 & No & Baseline & 9 \\
Xu et al. (2015) & 2024 & No & Baseline & 4 \\
Lu et al. (2017) & 2025 & No & & 12 \\
Huang et al. (2017) & 2025 & No & YES & 20 \\
PRIMAFF (2021) & 2030 & Yes & Baseline control & 7 \\
OECD/FAO (2021)) & 2030 & Yes & Baseline treatment & 7 \\
USDA (2021a) & $2030 / 2031$ & Yes & & 7 \\
This study & 2030 & Yes & & 7 \\
This study & 2030 & & & \\
\hline
\end{tabular}


Compared with previous studies, the simulation results of net imports in this paper (under the baseline control scenario) are similar to those of OECD/FAO (2021) and USDA (2021a). The figure would not exceed China's $7.2 \mathrm{mmt}$ tariff rate quota. However, the simulation results from $\mathrm{Lu}$ et al. (2017), Huang et al. (2017), and PRIMAFF (2021) are larger than 7.2 mmt. Huang et al. (2017) indicated that other studies might underestimate feed demand because they do not fully consider the rapid growth of maize used for processing, and they overestimate the gain from livestock feeding efficiency.

In 2017, the NBSC revised the statistical data for agriculture after 2007 according to the results of the Third National Agricultural Census and international practices. For example, maize production in 2016 was $219.6 \mathrm{mmt}$, according to the China Statistical Yearbook 2017. However, such data were revised to $263.6 \mathrm{mmt}$ in the China Statistical Yearbook 2018. Based on the revised statistical data, our balance sheet is different from Xu et al. (2015), Lu et al. (2017), and Huang et al. (2017), which brings our forecast results closer to reality (Table 7).

However, as shown in our study, China's net imports of maize in 2030 will reach $26 \mathrm{mmt}$ if the maize processing industry can develop freely. Since organizations, e.g., OECD/FAO, USDA, and PRIMAFF, mainly focus on baseline projection rather than scenario simulation, they assume that the policy will be stable in the future. Furthermore, since organizations publish projections annually, they can update the basic policy assumption accordingly when a new policy is issued. This study provides eight scenarios to simulate the possible impacts of China's bioethanol policy, which is our main contribution.

Moreover, China's maize market changed rapidly in 2020. As a short-term analysis reported by the (USDA, 2021b), China imported $26 \mathrm{mmt}$ of maize in 2020/2021, which is $18 \mathrm{mmt}$ higher than that in 2019/2020. The change, however, is a temporary phenomenon. First, China rebuilt and restructured its pig herd in 2020 after the African swine fever outbreak (OECD/FAO, 2021). Second, China increased for U.S. agricultural products after signing the Phase One agreement (USDA, 2021a). Third, imported maize was used for restocking in response to the impact of the COVID-19 epidemic, because China depleted its maize stock after five years of auction sales (USDA, 2021a). Thus, the long-term projections from the OECD/FAO (2021) and USDA (2021a) show that China's maize imports will return to normal after 2022.

Finally, there are still some limitations in this study due to the construction of a PE model with two sectors. The PE model only analyzes changes in the producer surplus and consumer surplus in a simple way whereas it is difficult to simulate the income effects and impacts of China's bioethanol policy on livestock products, food grains, and other coarse grains with this model (Huang et al., 2012b; Thornhill et al., 2016). This study, however, could only analyze the changes in producer surplus and consumer surplus in a simple way. It is suggested that future studies could focus on building a PE model with more sectors and a CGE model to investigate the impact of China's bioethanol policy on income and welfare. Furthermore, it is difficult to capture all the factors that affect the maize and bioethanol markets by our model. Further research may consider a variety of factors, including the development of new energy vehicles, exchange rates and other financial factors, stock variation, international relations, and increased fuel efficiency.

\section{Conclusion and policy implications}

This paper provides a multicountry and multisector PE model to simulate the effect of the bioethanol policy of China on the global maize market. The following conclusions and policy implications are derived from the projections.

First, under normal macroeconomic conditions, China's maize self-sufficiency ratio would decline from 98 to $92 \%$ by 2030 due to the bioethanol promotion policy. In the event of extreme macroeconomic growth, China's self-sufficiency in maize would drop to $84 \%$. Given the Chinese government's target of ensuring basic self-sufficiency of cereals, a self-sufficiency ratio of $92 \%$ to $84 \%$ would be viewed as challenging. Based on the scenario analysis, the Chinese government should take measures in advance to prepare for large-scale maize imports and to improve domestic maize productivity.

Second, under a bioethanol promotion policy, China could become one of the largest maize-importing countries worldwide. If the macroeconomy grows at a normal level, the net imports of maize in China will reach $26 \mathrm{mmt}$ in 2030. Meanwhile, major maize-exporting countries such as the United States, Brazil, Argentina, and Ukraine have the potential to expand their maize production and exports to meet China's import demand for maize. In this regard, we recommend that the Chinese government adjust its strategy in order to make better use of the international market. Furthermore, international trade and stock cooperation with maize import regions and countries should be strengthened.

Third, compared with the baseline control scenario, the bioethanol promotion policy of China could increase the world maize price index by $5 \%$ and the world bioethanol price index by $4 \%$. Thus, the international maize market could be influenced significantly by China's bioethanol promotion policy. Nevertheless, an increase in the price of maize and bioethanol could impact the prices of different food grains and livestock products. It is crucial to implement a long-term and stable bioethanol development policy 
to ensure food security as well as protect the interests of stakeholders in the maize industry.

Supplementary Information The online version contains supplementary material available at https://doi.org/10.1007/s12571-021-01212-5.

Acknowledgements The authors would like to thank Weiming Tian, Binlei Gong, Yi Che, and Funing Zhong for their valuable comments and suggestions during the 10th CAER-IFPRI Annual Conference, 2018. Any errors or omissions are the responsibility of the authors.

Funding This study is funded by the Agricultural Science and Technology Innovation Program (ASTIP-IAED-2021-SR-09 and ASTIP-IAED-2021-08), the National Natural Science Foundation of China (71473251), and the Central Public-interest Scientific Institution Basal Research Fund (No. Y2021ZK01, 161005202005-1, and 161005202007-2).

\section{Declarations}

Conflict of interest The authors declare that they have no conflicts of interest.

\section{References}

Araujo Enciso, S. R., Fellmann, T., Pérez Dominguez, I., \& Santini, F. (2016). Abolishing biofuel policies: Possible impacts on agricultural price levels, price variability and global food security. Food Policy, 61, 9-26. https://doi.org/10.1016/j.foodpol.2016.01.007

Bhalla, G., Handa, S., Angeles, G., \& Seidenfeld, D. (2018). The effect of cash transfers and household vulnerability on food security in Zimbabwe. Food Policy, 74, 82-99. https://doi.org/10.1016/j. foodpol.2017.11.007

Birur, D., Hertel, T., Tyner, W. (2008). Impact of biofuel production on world agricultural markets: A computable general equilibrium analysis (GTAP Working Paper No. 53)

Bosch, C., \& Zeller, M. (2019). Large-scale biofuel production and food security of smallholders: Evidence from Jatropha in Madagascar. Food Security, 11(2), 431-445. https://doi.org/10.1007/ s12571-019-00904-3

Bosch, M., \& Schady, N. (2019). The effect of welfare payments on work: Regression discontinuity evidence from Ecuador. Journal of Development Economics, 139, 17-27. https://doi.org/10.1016/j. jdeveco.2019.01.008

Chen, X. (2020). The core of China's rural revitalization: Exerting the functions of rural area. China Agricultural Economic Review, 12(1), 1-13. https://doi.org/10.1108/CAER-02-2019-0025

Chen, Y. (2004). China's food supply and demand and forecast. China Agriculture Press.

Chen, Y., Fan, Z., Gu, X., \& Zhou, L. A. (2020). Arrival of young talent: The send-down movement and rural education in china. American Economic Review, 110(11), 3393-3430. https://doi.org/ 10.1257/AER.20191414

Chinese Academy of Agricultural Sciences. (2021). China agricultural sector development report 2020. China Agricultural Science and Technology Press.

Deaton, A., \& Muellbauer, J. (1980). An almost ideal demand system. American Economic Review, 70(3), 312-326.

Devereux, S., Béné, C., \& Hoddinott, J. (2020). Conceptualising COVID-19's impacts on household food security. Food Security, 12(4), 769-772. https://doi.org/10.1007/s12571-020-01085-0
Fan, S., \& Agcaoili-Sombilla, M. (1997). Why projections on China's future food supply and demand differ. Australian Journal of Agricultural and Resource Economics, 41(2), 169-190. https://doi.org/ 10.1111/1467-8489.00009

Fang, K., Tang, Y., Zhang, Q., Song, J., Wen, Q., Sun, H., Ji, C., \& Xu, A. (2019). Will China peak its energy-related carbon emissions by 2030? Lessons from 30 Chinese provinces. Applied Energy, 255, 113852. https://doi.org/10.1016/j.apenergy.2019.113852

FAO. (2018). New food balances . Accessed April 6, 2018, from http:// www.fao.org/faostat/en/\#data/FBS

Feng, Z., Cai, T., Xiang, K., Xiang, C., \& Hou, L. (2019). Evaluating the impact of fossil fuel vehicle exit on the oil demand in China. Energies, 12(14), 2771. https://doi.org/10.3390/en12142771

Francois, J., \& Reinert, K. (1998). Applied methods for trade policy analysis: A handboo. Cambridge University Press.

Furuhashi, G. (2015). World food supply and demand projection to 2024 - projection results from the world food supply and demand model and scenario analysis of China's population changes. PRIMAFF Review, 5, 6-7.

Grote, U. (2014). Can we improve global food security? A socio-economic and political perspective. Food Security, 6(2), 187-200. https://doi.org/10.1007/s12571-013-0321-5

Haile, M. G., Kalkuhl, M., \& von Braun, J. (2014). Inter- and intraseasonal crop acreage response to international food prices and implications of volatility. Agricultural Economics, 45(6), 693710. https://doi.org/10.1111/agec. 12116

Han, J. (2020). Prioritizing agricultural, rural development and implementing the rural revitalization strategy. China Agricultural Economic Review, 12(1), 14-19. https://doi.org/10.1108/ CAER-02-2019-0026

Han, X. (2019). Corn projections in China: A globalization perspective. Economy \& Management Publishing House.

Han, X., Yang, S., Chen, Y., \& Wang, Y. (2019). Urban segregation and food consumption: The impacts of China's household registration system. China Agricultural Economic Review, 11(4), 583-599. https://doi.org/10.1108/CAER-07-2018-0153

Hoang, H. K., \& Meyers, W. H. (2015). Price stabilization and impacts of trade liberalization in the Southeast Asian rice market. Food Policy, 57, 26-39. https://doi.org/10.1016/j.foodpol.2015.07.009

Huang, J., Yang, J., Msangi, S., Rozelle, S., \& Weersink, A. (2012a). Biofuels and the poor: Global impact pathways of biofuels on agricultural markets. Food Policy, 37(4), 439-451. https://doi.org/ 10.1016/j.foodpol.2012.04.004

Huang, J., Yang, J., Msangi, S., Rozelle, S., \& Weersink, A. (2012b). Global biofuel production and poverty in China. Applied Energy, 98, 246-255. https://doi.org/10.1016/j.apenergy.2012.03.031

Huang, J. K., Wei, W., Cui, Q., \& Xie, W. (2017). The prospects for China's food security and imports: Will China starve the world via imports? Journal of Integrative Agriculture, 16(12), 2933-2944. https://doi.org/10.1016/S2095-3119(17)61756-8

Karp, L., \& Perloff, J. (2002). A synthesis of agricultural trade economics. In B. Gardner \& G. Rausser (Eds.), Handbook of agricultural economics. Elsevier.

Koizumi, T. (2015). Biofuels and food security. Renewable and Sustainable Energy Reviews, 52, 829-841. https://doi.org/10.1016/j. rser.2015.06.041

Kozicka, M., Kalkuhl, M., \& Brockhaus, J. (2017). Food grain policies in India and their implications for stocks and fiscal costs: A dynamic partial equilibrium analysis. Journal of Agricultural Economics, 68(1), 98-122. https://doi.org/10.1111/1477-9552.12176

Li, X., \& Yu, B. (2019). Peaking CO2 emissions for China's urban passenger transport sector. Energy Policy, 133, 110913. https:// doi.org/10.1016/j.enpol.2019.110913

Lopez, R. A., He, X., \& De Falcis, E. (2017). What drives China's new agricultural subsidies? World Development, 93, 279-292. https:// doi.org/10.1016/j.worlddev.2016.12.015 
Lu, W. C., Ning-lu, C., \& Wen-xin, Q. (2017). Modeling the effects of urbanization on grain production and consumption in China. Journal of Integrative Agriculture, 16(6), 1393-1405. https://doi. org/10.1016/S2095-3119(16)61602-7

Lv, X. (2013). Review of mid-and long-term predictions of China's grain security. China Agricultural Economic Review, 5(4), 567582. https://doi.org/10.1108/CAER-05-2013-0086

Macke, Y. (2017). Growing interest for ethanol brightens prospects (GAIN Report Number: CH17048). USDA

Meade, B., Regmi, A., James, L., Seale Jr., J., Muhammad, A. (2014). New international evidence on food consumption patterns: A focus on cross-price effects based on 2005 international comparison program data (Technical Bulletin Number: 1937). USDA

National Bureau of Statistics of China (NBSC). (2019). National database. Accessed May 16, 2019, from https://data.stats.gov.cn/easyq uery.htm?cn $=\mathrm{C} 01$

OECD. (2007). Documentation on the AGLINK-COSIMO. Model working party on agricultural policies and markets (AGR/CA/ APM(2006)16/FINAL). OECD

OECD. (2017). Agricultural policy monitoring and evaluation. OECD Publishing.

OECD/FAO. (2021). OECD-FAO agricultural outlook 2021-2030. OECD Publishing.

Oga, K., \& Yanagishima, K. (1995). International food and agricultural policy simulation model (IFPSIM): User's guide. Japan International Research Center for Agricultural Sciences.

Paudel, G. P., Krishna, V. V., \& McDonald, A. J. (2020). Apparent gains, hidden costs: Examining adoption drivers, yield, and profitability outcomes of rotavator tillage in wheat systems in Nepal. Journal of Agricultural Economics, 71(1), 199-218. https://doi. org/10.1111/1477-9552.12333

Peng, A. (2009). Introducing CGE models to the classroom using EXCEL. Available at SSRN 980561

Petrick, M., \& Zier, P. (2011). Regional employment impacts of common agricultural policy measures in Eastern Germany: A difference-in-differences approach. Agricultural Economics, 42(2), 183-193. https://doi.org/10.1111/j.1574-0862.2010.00509.x

Popp, J., Lakner, Z., Harangi-Rákos, M., \& Fári, M. (2014). The effect of bioenergy expansion: Food, energy, and environment. Renewable and Sustainable Energy Reviews, 32, 559-578. https://doi. org/10.1016/j.rser.2014.01.056

PRIMAFF. (2021). World food supply and demand projection to 2030 - projection results from the world food supply and demand model. PRIMAFF.

Qiu, H., Sun, L., Huang, J., \& Rozelle, S. (2012). Liquid biofuels in China: Current status, government policies, and future opportunities and challenges. Renewable and Sustainable Energy Reviews, 16(5), 3095-3104. https://doi.org/10.1016/j.rser.2012.02.036

Robinson, S., Mason d'Croz, D., Islam, S., Sulser, T., Robertson, R., Zhu, T., Gueneau, A., Pitois, G., Rosegrant, M. (2015). The international model for policy analysis of agricultural commodities and trade (IMPACT): Model description for version 3 (IFPRI Discussion Paper 1483)

Shan, M., Li, D., Jiang, Y., \& Yang, X. (2016). Re-thinking China's densified biomass fuel policies: Large or small scale? Energy Policy, 93, 119-126. https://doi.org/10.1016/j.enpol.2016.02.050

Sheng, Y., \& Song, L. (2019). Agricultural production and food consumption in China: A long-term projection. China Economic Review, 53, 15-29. https://doi.org/10.1016/j.chieco.2018.08.006

Thornhill, S., Vargyas, E., Fitzgerald, T., \& Chisholm, N. (2016). Household food security and biofuel feedstock production in rural Mozambique and Tanzania. Food Security, 8(5), 953-971. https:// doi.org/10.1007/s12571-016-0603-9

To, H., \& Grafton, R. Q. (2015). Oil prices, biofuels production and food security: Past trends and future challenges. Food Security, 7(2), 323-336. https://doi.org/10.1007/s12571-015-0438-9
Tomei, J., \& Helliwell, R. (2016). Food versus fuel? Going beyond biofuels. Land Use Policy, 56, 320-326. https://doi.org/10.1016/j. landusepol.2015.11.015

United Nations. (2015). World population prospects: The 2015 Revision, Volume I: Comprehensive tables. Department of Economic and Social Affairs.

USDA. (2021a). USDA agricultural projections to 2030. USDA.

USDA. (2021b). World agricultural supply and demand estimates (WASDE-612). USDA.

Valin, H., Sands, R. D., van der Mensbrugghe, D., Nelson, G. C., Ahammad, H., Blanc, E., Bodirsky, B., Fujimori, S., Hasegawa, T., Havlik, P., Heyhoe, E., Kyle, P., Mason-D’Croz, D., Paltsev, S., Rolinski, S., Tabeau, A., van Meijl, H., von Lampe, M., \& Willenbockel, D. (2014). The future of food demand: Understanding differences in global economic models. Agricultural Economics, 45(1), 51-67. https://doi.org/10.1111/agec.12089

Von Lampe, M., Willenbockel, D., Ahammad, H., Blanc, E., Cai, Y., Calvin, K., Fujimori, S., Hasegawa, T., Havlik, P., Heyhoe, E., Kyle, P., Lotze-Campen, H., Mason d'Croz, D., Nelson, G. C., Sands, R. D., Schmitz, C., Tabeau, A., Valin, H., van der Mensbrugghe, D., ... van Meijl, H. (2014). Why do global long-term scenarios for agriculture differ? An overview of the AgMIP global economic model intercomparison. Agricultural Economics, 45(1), 3-20. https://doi. org/10.1111/agec.12086

Xu, J., Yuan, Z., \& Chang, S. (2018). Long-term cost trajectories for biofuels in China projected to 2050. Energy, 160, 452-465. https:// doi.org/10.1016/j.energy.2018.06.126

Xu, S. W., Li, G. Q., \& Li, Z. M. (2015). China agricultural outlook for 2015-2024 based on China agricultural monitoring and earlywarning system (CAMES). Journal of Integrative Agriculture, 14(9), 1889-1902. https://doi.org/10.1016/S2095-3119(15)61149-2

Yan, Y., Wang, D., Wang, J., Wang, X., \& Liu, X. (2019). National and regional food security and sustainable development against the backdrop of internationalization and greenization. Strategic Study of CAE, 21(5), 10-18. https://doi.org/10.15302/J-SSCAE-2019.05.002

Zhang, H. (2015). Development of biofuels in China: Progress, government policies and future prospects. Copenhagen Journal of Asian Studies, 33(1), 40-63. https://doi.org/10.22439/cjas.v33i1.4811

Zilberman, D., Hochman, G., Rajagopal, D., Sexton, S., \& Timilsina, G. (2013). The impact of biofuels on commodity food prices: Assessment of findings. American Journal of Agricultural Economics, 95(2), 275-281. https://doi.org/10.1093/ajae/aas037

Zimmerer, K. S., \& de Haan, S. (2020). Informal food chains and agrobiodiversity need strengthening — not weakening - to address food security amidst the COVID-19 crisis in South America. Food Security, 12(4), 891-894. https://doi.org/10.1007/s12571-020-01088-x

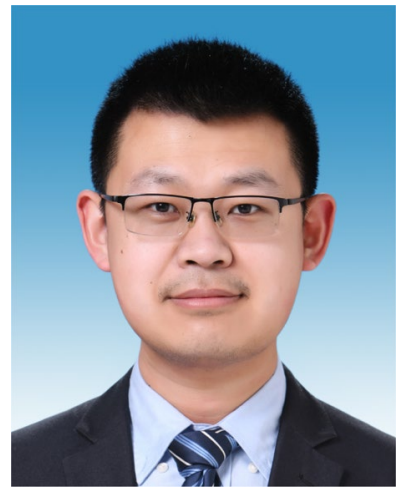

Xinru Han is Associate Professor in the Institute of Agricultural Economics and Development, Chinese Academy of Agricultural Sciences. He received the $\mathrm{PhD}$ Degree in International Economics from China Agricultural University. Currently, his research focuses on the supplydemand analysis and food security. 


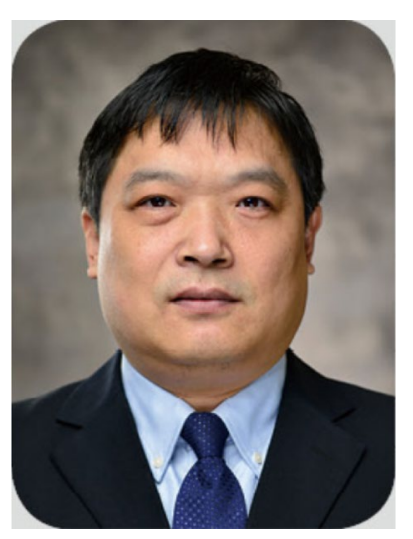

Yongfu Chen is Professor in the College of Economy and Management, China Agricultural University. He received a $\mathrm{PhD}$ Degree from the Ehime University of Japan. His research interests are in the supply-demand analysis of agricultural products and agricultural trade.

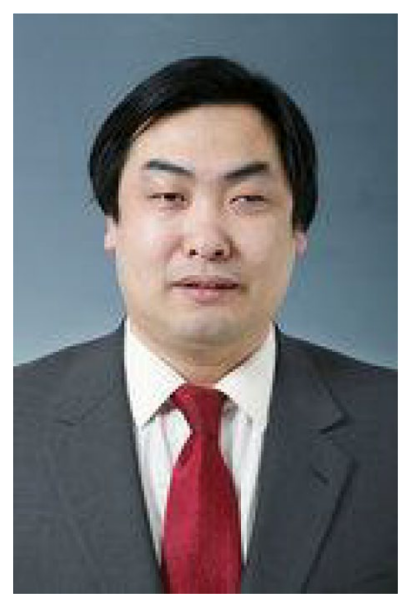

Xiudong Wang is Professor in the Institute of Agricultural Economics and Development, Chinese Academy of Agricultural Sciences. He received a $\mathrm{PhD}$ Degree in Agricultural Economics and Management from the Chinese Academy of Agricultural Sciences. He currently focuses on food security and agricultural policy. 